ISSN = 1980-993X - doi:10.4136/1980-993X
www.agro.unitau.br/ambi-agua
E-mail: ambi-agua@agro.unitau.br
Tel.: (12) 3625-4116

\title{
Heterotrophic components of soil respiration in pastures and forests in southwestern Amazonia, Acre, Brazil \\ (doi:10.4136/ambi-agua.58)
}

\author{
Cleber Ibraim Salimon ${ }^{1}$; Eric Atlas Davidson ${ }^{2}$ \\ ${ }^{1}$ Universidade Federal do Acre, BR 364 km 4, CEP 69915-900 - Rio Branco, AC \\ E-mail: clebsal@gmail.com \\ ${ }^{2}$ The Woods Hole Research Center, 149 Woods Hole Road, Falmouth, MA \\ 02540-1644, USA \\ E-mail: edavidson@whrc.org
}

\begin{abstract}
In this paper we present data on soil microbial biomass and heterotrophic respiration in pastures, mature and secondary forests, in order to elucidate their contribution to total $\mathrm{CO}_{2}$ flux from soil to atmosphere. The research was conducted in Southwestern Amazonia, Acre State, Brazil. Microbial biomass was estimated using a variation of the traditional fumigationextraction method and heterotrophic respiration was measured using respirometry flasks attached to an infrared gas analyzer. Soil microbial biomass and heterotrophic respiration did not differ statistically among pastures, mature and secondary forests. These laboratory results indicate that higher $\mathrm{CO}_{2}$ fluxes from pasture soils measured in situ are probably due to higher root respiration by pasture grasses.
\end{abstract}

Keywords: soil microbial biomass; $\mathrm{CO}_{2}$ flux; heterotrophic respiration.

\section{Componentes heterotróficos da respiração em solos de pastagens e florestas na Amazônia Sul-Ocidental, Acre, Brasil}

\section{RESUMO}

No presente trabalho são apresentados dados sobre biomassa microbiana do solo e respiração heterotrófica em pastagens, florestas maduras e secundárias, no intuito de elucidar a sua contribuição para os fluxos totais de $\mathrm{CO}_{2}$ do solo para atmosfera. $\mathrm{O}$ trabalho foi realizado na Amazônia sul-ocidental, no estado do Acre. A biomassa microbiana foi estimada com base em uma variação do tradicional método de fumigação-extração e a respiração heterotrófica foi medida utilizando-se frascos para respirometria e um analisador de gás por infravermelho. Tanto biomassa microbiana do solo quanto respiração heterotrófica foram similares em pastagens e florestas. Com base nos resultados, concluiu-se que os maiores fluxos de $\mathrm{CO}_{2}$ do solo para a atmosfera, in situ, observados em pastagens, devem ser fruto da respiração radicular.

Palavras-chave: biomassa microbiana do solo; fluxo de $\mathrm{CO}_{2}$; respiração heterotrófica. 


\section{INTRODUCTION}

The flux of $\mathrm{CO}_{2}$ has been addressed in many studies in amazonian ecosystems in a variety of ways, from net ecosystem fluxes from tower measurements by eddy covariance techniques (Malhi et al., 1998; Miller et al., 2004), from soil to atmosphere (Salimon et al., 2004; Davidson and Trumbore, 1995; Sotta et al., 2004), to fluxes from rivers to the atmosphere (Richey et al., 2002).

One important aspect still to be elucidated in these multi level studies of $\mathrm{CO}_{2}$ flux in terrestrial ecosystems is the separation and quantification of autotrophic and heterotrophic respiration, because each of these components is important for understanding net ecosystem exchanges and balance (Chambers et al., 2004).

Land cover change is also another factor to be focused on, since the rate of soil respiration differs between pastures and forests in the Amazon, and it has been shown that in southwestern Amazonia, pastures increase $\mathrm{CO}_{2}$ flux from soil at the landscape scale since grasses present respiration rates that are higher than forests (Salimon et al., 2003).

Although separation of heterotrophic and autotrophic respiration is a very important issue (Millard et al., 2008) for the improvement of our understanding on the effects of land cover change on carbon fluxes and balances it is worth mentioning that to date it has not been addressed yet for the Amazon region.

Therefore, the main goal of this study was to determine if soil heterotrophic respiration follows the same pattern as total $\mathrm{CO}_{2}$ flux from soil to atmosphere in pastures and forests presented by Salimon et al. (2004). If heterotrophic respiration is equal to or less in pastures than in forests, then we can assume that the higher total flux in pastures is due to autotrophic respiration, because the total flux is the sum of hetero and autotrophic respiration.

For such purpose, we (1) determined the soil microbial biomass and (2) quantified heterotrophic soil respiration in pasture, secondary and mature forests.

\section{MATERIAL AND METHODS}

The present study was conducted in southwestern Amazonia, in the state of Acre, Brazil. Soils are predominantly ultisols and some patches of oxisols. Although both types of soils are mostly distrophyc, ultisols in Acre tend to be less poor in nutrients, with higher concentrations of $\mathrm{Ca}^{2+}$ and $\mathrm{Mg}^{2+}$ (Salimon et al., 2007). On the plateaus and upland the forest is classified as ombrophilous open forest, with patches of bamboo dominated areas and in the alluvial plains, where soils are usually gleysols, ombrophilous dense forest dominate the valleys with many palms. Mean annual temperature is $26^{\circ} \mathrm{C}$ and mean annual precipitation is $1940( \pm 228) \mathrm{mm}$ (Duarte, 2005).

The state has about $10 \%$ of its natural cover already deforested and the annual deforestation rate varies from 0.26 to $0.83 \%$ between 1977 and 2006 (INPE, 2007). The southwestern part of the state is the most deforested region, where more than $50 \%$ has already been deforested. Where the forest has been converted, $60 \%$ has turned into pasture for cattle ranching and subsistence agriculture and $40 \%$ is in some stage of secondary succession (Salimon et al., 2003).

Specifically, this study was conducted in two government sponsored settlements, (1) Peixoto Settlement Project and (2) Humaitá Settlement Project, hereafter referred to as Peixoto and Humaitá. In both settlements the main animal products are cattle and chickens and the principal crops are manioc, maize, banana, and rice. The typical land holding is about 120 ha located along access roads. A detailed description of each of the sampling sites is presented on Table 1. 
Soil microbial carbon biomass was estimated using an adaptation of the conventional fumigation and extraction method (Powson and Jenkinson, 1976; Feigl et al., 1995; Hanson et al., 2000). This alternative method, described below, was used due to laboratory and field conditions available in the Zoobotanical Park of the Federal University of Acre, Brazil. The main adaptations of the method were in relation to (1) methyl trichloride evaporation, which was carried out in a dry oven at $40^{\circ} \mathrm{C}$; and (2) carbon analysis which was carried out in an elemental analyzer.

Table 1. Sampling sites and their descriptions. Age of pastures and secondary forests refer to the year 2000. Names correspond to cover, where $\mathrm{P}$ - pasture, $\mathrm{C}$ - secondary forests and F - mature forests; numbers indicate the age of each pasture and secondary forest.

\begin{tabular}{|c|c|c|c|c|c|}
\hline \multirow{2}{*}{\multicolumn{2}{|c|}{ Sampling Site }} & \multicolumn{2}{|c|}{ Lat/Long } & \multirow{2}{*}{$\begin{array}{c}\text { Land cover and } \\
\text { age }\end{array}$} & \multirow{2}{*}{$\begin{array}{l}\text { Previous } \\
\text { cover }\end{array}$} \\
\hline & & $\mathrm{S}$ & $\mathrm{W}$ & & \\
\hline \multirow{3}{*}{ 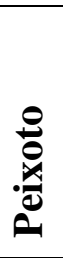 } & pasture13 & $9^{\circ} 52^{\prime} 27.6^{\prime \prime} \mathrm{S}$ & $67^{\circ} 4^{\prime} 19.2^{\prime \prime} \mathrm{W}$ & 13 year old pasture & $\begin{array}{l}\text { Mature } \\
\text { forest }\end{array}$ \\
\hline & secfor3a & $9^{\circ} 52^{\prime} 30.1 ' \prime \mathrm{S}$ & $67^{\circ} 4{ }^{\prime} 26.9^{\prime \prime} \mathrm{W}$ & $\begin{array}{l}\text { Three years old } \\
\text { secondary forest }\end{array}$ & $\begin{array}{l}\text { Manioc } \\
\text { plantation }\end{array}$ \\
\hline & matfora & $9^{\circ} 52^{\prime} 36.7^{\prime \prime} \mathrm{S}$ & $67^{\circ} 4{ }^{\prime} 37.9^{\prime \prime} \mathrm{W}$ & Mature forest & --- \\
\hline \multirow{3}{*}{ 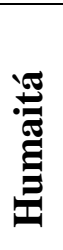 } & pasture14 & $9^{\circ} 46^{\prime} 12.8^{\prime \prime} \mathrm{S}$ & $67^{\circ} 39^{\prime} 28.7^{\prime \prime} \mathrm{W}$ & 14 year old pasture & $\begin{array}{l}\text { Mature } \\
\text { forest }\end{array}$ \\
\hline & secfor $3 b$ & $9^{\circ} 46^{\prime} 14.9$ '’ $\mathrm{S}$ & $67^{\circ} 39^{\prime} 27.9^{\prime \prime} \mathrm{W}$ & $\begin{array}{l}\text { Three years old } \\
\text { secondary forest }\end{array}$ & $\begin{array}{l}\text { Rice/beans } \\
\text { plantation }\end{array}$ \\
\hline & matforb & $9^{\circ} 46^{\prime} 13.5^{\prime \prime} \mathrm{S}$ & $67^{\circ} 39^{\prime} 29.1^{\prime \prime} \mathrm{W}$ & Mature forest & --- \\
\hline
\end{tabular}

Three soil samples were taken from each site in two depths $(0-5$ and 5-10 cm). Samples were taken to the lab and sieved through a $1 \mathrm{~mm}$ mesh size sieve. After a period of acclimation of three days in the dark at constant temperature of $25^{\circ} \mathrm{C}$ (Feigl et al., 1995), each sample was split into two sub-samples, one as control and the other for fumigation with methyl trichloride. From the control sub samples we extracted $15 \mathrm{~g}$ of soil which were placed in $100 \mathrm{ml}$ flasks and then mixed with $75 \mathrm{ml}$ of a $\mathrm{K}_{2} \mathrm{SO}_{4} 0.5 \mathrm{M}$ solution, for the soluble soil carbon extraction. After addition of this solution, each sample flask was agitated vigorously for two minutes and then settled for $24 \mathrm{~h}$ at $25^{\circ} \mathrm{C}$. After this period, samples were sieved in a fiber glass filter $(0.7 \mu \mathrm{m}$ nominal porosity) and the filtered solution was frozen for later carbon analysis.

For the fumigated sub-samples, $15 \mathrm{~g}$ of soil were placed in $100 \mathrm{ml}$ flask together with 4 $\mathrm{ml}$ of pure methyl trichloride, and left with its lid closed for $48 \mathrm{~h}$ at $25^{\circ} \mathrm{C}$, after which the flasks were open and left in a dry oven at $40^{\circ} \mathrm{C}$ for five hours until complete methyl trichloride evaporation. After this procedure $75 \mathrm{ml}$ of $\mathrm{K}_{2} \mathrm{SO}_{4}$ 0,5 $\mathrm{M}$ were added to the soil and then all the process described for the control sub-samples were repeated.

The frozen sub-samples were taken to the Isotopic Ecology Laboratory of the Center of Nuclear Energy to Agriculture (CENA) at the University of São Paulo, where they were defrosted and subsequently dehydrated at constant temperature of $50^{\circ} \mathrm{C}$ for 72 hours in a dry oven. The resultant salt, which contained the soluble carbon extracted from the soil was then taken to an Element Analyzer Carlo Erba 1110 CNHS.

Microbial biomass was estimated by using the $\mathrm{C}$ concentration of the fumigated and the control soil samples, using a correction factor for $\mathrm{C}$ content in microbial biomass ( $\mathrm{k}$ factor) proposed by Feigl et al. (1995), who have determined a specific value for tropical soils. 
One way of separating $\mathrm{CO}_{2}$ flux into heterotrophic and autotrophic components is by in vitro respirometry essays, where the live plant material is extracted from the soil, so that the flux values measured will be resultant only from the heterotrophic respiration. This methodology serves for semi-quantitative comparisons with in situ data, where autotrophic respiration is included as well. Salimon et al. (2004) showed that higher total $\mathrm{CO}_{2}$ fluxes from soil were observed in pastures and not in forests based on in situ data from the exact same sites of the present study. A fully quantitative comparison cannot be possible since the quantity of soil involved and environmental conditions (such as soil bulk density, aeration, temperature, among others) are distinct for each method. Nonetheless, with such approach, we can conjecture about the importance of the heterotrophic and autotrophic components of soil respiration and therefore, contribute to the understanding of the effects of land cover change on the carbon cycling in the Amazon.

In vitro heterotrophic respiration was measured with a respirometer (a $600 \mathrm{ml}$ glass bottle with two stopcocks, attached to tubings which were connected to an infrared gas analyzer (IRGA - LICOR-6252). The IRGA was calibrated every morning by using 'zero' air that had been run through a soda lime scrubber and by using a White Martins certificated standard gas of $610( \pm 2 \%)$ ppmv of $\mathrm{CO}_{2}$ (nitrogen as balance gas).

At each land cover type (pasture, secondary and mature forest) five soil samples were taken from 0-5 cm depth. Each sample was sieved ( $1 \mathrm{~mm}$ mesh) for root extraction and then it was homogenized and left at constant temperature of $25^{\circ} \mathrm{C}$ for three days for acclimation of all samples and treatments (land cover type). After acclimation $20 \mathrm{~g}$ of soil from each sample were placed inside a respirometer (five replicates for each land cover type). The respirometer was then closed and the increase in $\mathrm{CO}_{2}$ concentration was recorded with the IRGA every hour for 12 hours.

With the $\mathrm{CO}_{2}$ concentration data, we then made regressions with time to estimate the fluxes, taking into account the volume of the respirometer and tubings, gas constants and temperature. This heterotrophic respiration essay was carried out in four occasions: November 2001, March 2002, April 2002 and July 2002, in order to identify if there was any change throughout the seasons.

We took sub-samples from each soil sample for the heterotrophic respiration in order to estimate volumetric water content, by oven-drying these sub-samples at $110^{\circ} \mathrm{C}$ for 72 hours.

Statistical analyses were carried out using non parametric tests, since our data did not fit into a normal distribution, neither presented homogeneity of variances (Sokal and Rohlf, 1995).

\section{RESULTS AND DISCUSSION}

The results for soil microbial biomass estimation for pasture, secondary and mature forest are presented on Table 2 .

The highest observed value for $\mathrm{C}$ content was for a secondary forest $(156 \pm 26 \mu \mathrm{g} \mathrm{C} \mathrm{g}$ soil $\left.^{-1}\right)$ and the lowest was for a mature forest $\left(65 \pm 55 \mu \mathrm{g} \mathrm{C} \mathrm{g} \mathrm{soil}{ }^{-1}\right)$. With the exception of one secondary forest $(\mathrm{C} 3 \mathrm{~B})$, all sampled sites presented higher microbial biomass between 0 and $5 \mathrm{~cm}$ depth.

Both pasture and forests (mature and secondary) presented similar values for C content in the soil microbial biomass and the differences were not statistically significant $(p>0.05-$ Kruskal-Wallis test).

A comparison of these results with data from other authors should be taken carefully since biomass estimation in the present study was made using an alternative method that is different from the ones used in the current literature. For instance, the numbers presented here 
are much lower than the ones presented by Feigl et al. (1995) for other site in Amazonia, with values ranging from 390 to $580 \mu \mathrm{g} \mathrm{C} \mathrm{g} \mathrm{soil}{ }^{-1}$.

Although there is no direct relationship between soil microbial biomass and heterotrophic respiration, the similarity of values presented among pasture, secondary and mature forests can be considered as an indicative of similar rates of heterotrophic respiration, which was indeed observed and described hereafter.

Table 2. Microbial biomass in pastures, secondary and mature forests; values in parenthesis are for standard deviation $(n=3)$.

Numbers in the acronyms of each site correspond to the age of the land cover.

\begin{tabular}{llrc}
\hline & & \multicolumn{2}{c}{$\begin{array}{c}\text { Microbial Biomass } \\
\left(\mu \mathbf{g ~ C} \text { g soil }^{-\mathbf{1}}\right)\end{array}$} \\
& Sampling site & 0-5 cm & $\mathbf{1 0 - 2 0 ~ c m}$ \\
\hline Peixoto & Secfor3a & $156(26)$ & $52(52)$ \\
& matfora & $65(55)$ & $26(37)$ \\
& pasture 13 & $147(75)$ & $95(54)$ \\
Humaitá & Secfor3b & $69(15)$ & $69(15)$ \\
& matforb & $95(40)$ & $35(15)$ \\
& pasture14 & $69(30)$ & $35(40)$ \\
\hline
\end{tabular}

Soil volumetric water content of samples, varied from 13 to $36 \%$ (Table 3 ), where pastures always presented higher values than forests ( $\mathrm{p}<0.05$ - Kruskal-Wallis test), except for the April 2002 essay. The higher water content in pasture soils does not mean necessarily more available water to microbes or roots, since pastures also present higher clay content probably due to more intense erosion processes (Salimon et al., 2007). Such higher clay content, although retaining more water, makes it harder to be extracted by organisms due to capillary forces in the mineral particles.

Table 3. Soil volumetric water content (\%) in each of the Peixoto sampling sites for the respirometry essays $(n=4)$. Numbers in the acronyms of each site correspond to the age of the land cover.

\begin{tabular}{lcccc}
\hline & Nov/01 & Mar/02 & Apr/02 & Jul/02 \\
\hline Secfor3a & $15.0(1.4)$ & $14.4(1.1)$ & $29.8(2.2)$ & $18.7(0.4)$ \\
matfora & $16.4(1.0)$ & $13.5(1.9)$ & $28.8(1.6)$ & $19.6(0.4)$ \\
Pasture13 & $19.9(1.7)$ & $19.9(2.3)$ & $35.4(4.4)$ & $23.1(0.5)$ \\
\hline
\end{tabular}

No clear trend was observed among treatments or in the seasons, although the highest values for all treatments were observed in July 2002 (Table 4 and Figure 1)

In November 2001 the mature forest presented the highest respiration, followed by the secondary forest and the lowest value was observed for the pasture. In March 2002 the highest respiration was observed in the pasture samples, followed by secondary and mature forests, respectively. In April 2002, secondary forest samples presented the highest values, and in July 2002, mature forest samples again presented the highest values. 
Table 4. In vitro heterotrophic respiration for the Peixoto sites (southeast of the state of Acre). Values in $\mu \mathrm{g} \mathrm{C} \mathrm{g} \operatorname{soil}^{-1} \mathrm{~h}^{-1}$; standard deviation in parenthesis $(\mathrm{n}=5)$.

\begin{tabular}{l|ccc}
\hline & Secondary forest & Mature forest & Pasture \\
\hline November 2001 & $0.58(0.1)$ & $0.79(0.1)$ & $0.47(0.1)$ \\
March 2002 & $0.74(0.1)$ & $0.66(0.2)$ & $0.97(0.3)$ \\
April 2002 & $0.34(0.0)$ & $0.65(0.2)$ & $0.54(0.2)$ \\
July 2002 & $1.69(0.2)$ & $1.91(0.5)$ & $1.69(0.3)$ \\
\hline
\end{tabular}

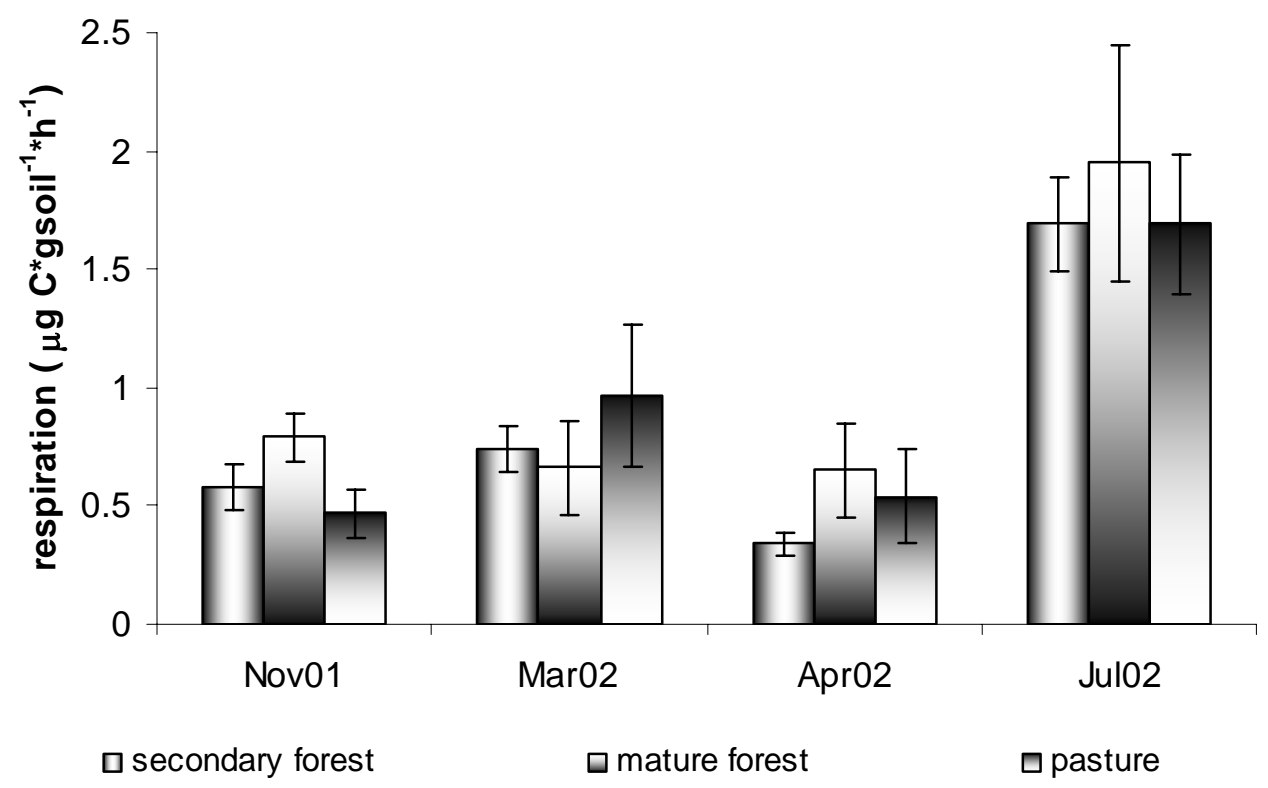

Figure 1. In vitro heterotrophic respiration in secondary forest, mature forest and pasture at the Peixoto study area (southeast of the state of Acre).

When statistically comparing treatments (Kruskal-Wallis, $\mathrm{p}>0.05$; and Multiple Comparison of Mean Ranks tests, $\mathrm{p}>0.05$ ) in each of the four essays, we observe that in November 2001, mature and secondary forests presented similar respiration rates, but significantly higher than pasture. In March 2002 only pasture and mature forest were significantly different, while in April and July 2002 there was no significant difference among treatments. Based on these statistical results, we did not observe any pattern suggesting that any of the land cover types studied present significant differences in heterotrophical respiration

Contrary to these findings, Salimon et al. (2004) showed that pastures presented greater $\mathrm{CO}_{2}$ from soil than mature and secondary forests. If heterotrophic respiration rates are not consistently different among treatments, but total $\mathrm{CO}_{2}$ flux in situ is higher in pastures, then autotrophic respiration could be the most probable cause for higher total fluxes in pasture soils. Grasses in these productive pastures could be allocating part of its carbon bellow ground, supporting the high root respiration rates.

Although the values presented here cannot be quantitatively used for estimating the exact percent contribution of autotrophic and heterotrophic respiration in total $\mathrm{CO}_{2}$ flux from soil, we can infer that autotrophic contribution is higher, since with the removal of roots from the soil, pasture's respiration (in vitro) is not different than in forests.

Also, Salimon et al. (2004) showed that the $\delta^{13} \mathrm{C}$ of total respired $\mathrm{CO}_{2}$ in the pasture soil was $-14 \%$, which is very close to $-13 \%$ of the Brachiaria brizantha dominant grass in these pastures, suggesting that most of the carbon released during respiration has a $\mathrm{C} 4$ plant 

southwestern Amazonia, Acre, Brazil. Ambi-Agua, Taubaté, v. 3, n. 3, p. 20-27, 2008. (doi:10.4136/ambiagua.58)

signature, which comes from the pasture's grasses. This finding also corroborates with our results here.

\section{CONCLUSION}

Even from the semi-quantitative results presented here and based on unusual techniques, we suggest that root respiration is the largest component responsible for the higher total in situ $\mathrm{CO}_{2}$ fluxes from soil in pastures, since both soil microbial biomass and soil heterotrophic respiration did not differ significantly between pasture and forests.

\section{ACKNOWLEDGEMENTS}

We would like to thank Reynaldo Luiz Victoria and Susan Trumbore for valued discussions; Antonio Willian Flores de Melo and Jorcinei W. Pereira for field and lab work. This research was funded by FAPESP process 99/03315-3 and NASA LBA-ECO grants NCC5-332, NCC5-686, and NNG06GE88A.

\section{REFERENCES}

ACRE. Zoneamento ecológico-econômico do estado do Acre. Rio Branco: Governo do Estado do Acre, 2000.

CHAMBERS, J. Q.; TRIBUZY, E. S.; TOLEDO, L. C.; CRISPIM, B. F.; HIGUCHI, N.; DOS SANTOS, J., et al. Respiration from a tropical forest ecosystem: partitioning of sources and low carbon use efficiency. Ecological Applications, v. 14, n. 4, p. S72S88, Supplement, 2004.

DAVIDSON, E. A.; TRUMBORE, S. E. Gas diffusivity and production of $\mathrm{CO}_{2}$ in deep soils of the eastern Amazonia. Tellus, v. 4, n. 47B, p.550-565, 1995.

DUARTE, A. F. Variabilidade e tendência das chuvas em Rio Branco, Acre, Brasil. Revista Brasileira de Meteorologia, v. 20, n. 1, p. 37-42, 2005.

FEIGL, B. J.; SPARLING, G. G.; ROSS, D. J.; CERRI, C. C. Soil microbial biomass in Amazonian soils: evaluation of methods and estimates of pool sizes. Soil Biology and Biochemistry, v. 27, n. 11, p. 1467-1472, 1995.

HANSON, P. J.; EDWARDS, N. T.; GARTEN, C. T.; ANDREWS, J. A. Separating root and soil microbial contributions to soil respiration: a review of methods and observations. Biogeochemistry, v. 48, p. 115-146, 2000.

INSTITUTO NACIONAL DE PESQUISAS ESPACIAIS. Monitoramento da floresta amazônica por satélite, Projeto PRODES. São José dos Campos: INPE, 2007. Disponível em: <http://www.obt.inpe.br/prodes/>. Acesso em: nov. 2007.

MALHI, Y.; NOBRE, A. D.; GRACE, J.; KRUIJT, B.; PEREIRA, M. G. P.; CULF, A., et al. Carbon dioxide transfer over a Central Amazonian rain forest. Journal of Geophysical Research-Atmospheres, v. 103, p. 31593-31612, 1998.

MILLARD, P.; MIDWOOD, A. J.; HUNT, J. E.; WHITEHEAD, D.; BOUTTON, T. W. Partitioning soil surface $\mathrm{CO} 2$ efflux into autotrophic and heterotrophic components, 
using natural gradients in soil delta C-13 in an undisturbed savannah soil. Soil Biology \& Biochemistry, v. 40, n. 7, p. 1575-582, 2008.

MILLER, S. M.; GOULDEN, M. L.; MENTON, M. C.; ROCHA, H. R.; FREITAS, H. C.; FIGUEIRA, A. M. S., et al. Biometric and micrometeorological measurements of tropical Forest carbon balance. Ecological Monographs, v. 14, n. 4, p. S114-S126, supplement, 2004.

PETRI, S.; FULFARO, V. J. Geologia do Brasil. São Paulo: EDUSP, 1988. 631p,

POWLSON, D. S.; JENKINSON, D. S. The effects of biocidal treatments on metabolism in soil - II. Gamma irradiation, autoclaving, air-drying and fumigation. Soil Biology and Biochemistry, v. 8, p. 179-188, 1976.

RICHEY, J. E.; MELACK, J. M.; AUFDENKAMPE, A. K.; BALLESTER, V. M.; HESS, L. L. Outgassing from Amazonian rivers and wetlands as a large tropical source of atmospheric $\mathrm{CO}_{2}$. Nature, v. 416, p. 617-620, 2002.

SALIMON, C. I.; VICTORIA R. L.; BROWN, I. F.; STONE, T. A.; DAVIDSON, E. A. Mudança de Cobertura da Terra e Fluxo de $\mathrm{CO}_{2}$ do solo para atmosfera na Amazônia Sul-ocidental. In: SEMINÁRIO BRASILEIRO DE SENSORIAMENTO REMOTO, 11, 2003, Belo Horizonte. Anais... São José dos Campos: INPE, 2003. p. 699-705.

SALIMON, C. I.; DAVIDSON, E. A.; VICTORIA, R. L.; MELO, A. W. F. $\mathrm{CO}_{2}$ flux from soil in pastures and forests in southwestern Amazonia. Global Change Biology, v. 10, n. 5 , p. $833-843,2004$.

SALIMON, C. I.; WADT, P.; MELO, A. W. F. Dinâmica do Carbono na conversão de floresta para pastagens em argissolos da formação geológica solimões, no sudoeste da Amazônia. Revista de Biologia e Ciências da Terra, v. 7, p. 29 - 38, 2007.

SOKAL, R. R.; ROHLF, F. J. Biometry. New York: W. H. Freeman and company, 1995.

SOTTA, E. D.; MEIR, P.; MALHI, Y.; NOBRE, A. D.; HODNETT, M.; GRACE, J. Soil CO efflux in a tropical forest in the central Amazon. Global Change Biology, v. 10, n. 5, p. 601-617, 2004. 